\title{
Comparative study of alprenolol and methyldopa in previously untreated essential hypertension
}

\author{
J. Anders Vedin, Claes-E. Wilhelmsson, and Lars Werkö \\ From the Department of Internal Medicine I, Sahlgren's hospital, Gothenburg, Sweden
}

The effects of methyldopa and alprenolol were compared in 15 patients with previously untreated essential hypertension. The patients were randomly allocated to start treatment with one of the drugs. All blood pressures and side effects were registered blindly as regards type of treatment by the same observer. The study was not blind as regards the patients as non-matching tablets were used. Alprenolol (using a dosage of 400 or $800 \mathrm{mg}$ per day) was shown to be more effective than methyldopa (750 or $1500 \mathrm{mg}$ per day) in lowering the resting supine and erect arterial systolic and diastolic blood pressures. During exercise (bicycle ergometer, I0O W) no statistically significant difference between the two drugs could be shown. The systolic and diastolic resting supine blood pressures after three months of alprenolol treatment and one month of subsequent placebo administration were still significantly lower than the initial pressures.

In recent years adrenergic beta-receptor-blocking agents have attracted increasing attention as antihypertensive agents (Paterson and Dollery, 1966; Prichard and Gillam, 1966; Tibblin and Åblad, 1969; Zacharias and Cowen, 1970; Zacharias et al., 1972; Bengtsson, 1972; Hansson et al., 1972). The present report deals with a comparison of the established antihypertensive drug methyldopa and alprenolol, a beta-blocking agent which has some intrinsic stimulating activity (Åblad, Brogård, and Ek, 1967; Johnsson et al., 1969; Sannerstedt et al., 1971, 1972).

\section{Subjects and methods}

The trial comprised is male patients with previously undetected essential hypertension. The patients were admitted to the trial if the pressure measured in the sitting position and subsequently in the supine position after five minutes' rest and determined within two weeks of the pressure in the sitting position were both above I $10 \mathrm{mmHg}$ diastolic. Applying the WHO classification, I4 patients were classified as stage $I$ and $I$ patient as stage 2. Ages and some background data are shown in Table I.

The study was designed as a crossover trial. The patients were randomly allocated to either drug. Group I consisted of those who later turned out to have started with alprenolol $(\mathrm{N}=7)$, and group 2 consisted of those

Received II July 1973. starting with methyldopa $(\mathrm{N}=8)$. A starting dose of $400 \mathrm{mg}$ daily of alprenolol (Group I) or $750 \mathrm{mg}$ daily of methyldopa (Group 2)was used. Alprenolol was given as a sustained release preparation twice a day and methyldopa three times a day. The commercially available preparations were used.

The patients were instructed to take doses at 8 am and $8 \mathrm{pm}$. When on methyldopa treatment the third dose was taken between $\mathrm{I}$ and $2 \mathrm{pm}$.

No other drug but the trial drug was administered during the study.

If after four weeks of initial treatment, the patients had a systolic and diastolic blood pressure below 160 and $95 \mathrm{mmHg}$, respectively (responders), the dose was not further increased. Otherwise the daily dose was increased to $800 \mathrm{mg}$ of alprenolol or $1500 \mathrm{mg}$ of methyldopa. No further dose adjustments were made during the trial. All patients were maintained on the final individual dose level for 8 weeks.

The initial treatment period of 3 months (Period I) was then followed by a 4-week 'wash-out period' when placebo tablets were given twice a day. After the 'washout period' the patients were switched over from alprenolol to methyldopa and vice versa (period II). Otherwise the second treatment period (period II) was identical to the first.

The staff performing the present trial was divided into two parts. One physician supplied the patients with the trial drugs and also served as the patients' principal physician. Another physician, with no knowledge of the actual treatment, handled all blood pressure measurements and recorded adverse effects according to a 
TABLE I Age, body-weight, stage of disease according to the WHO-classification, serum creatinine, and final dosage levels of alprenolol and methyldopa in 15 patients: mean values are shown for age, body weight, and serum creatinine

\begin{tabular}{|c|c|c|c|c|c|c|}
\hline Case No. & $\begin{array}{l}\text { Age } \\
(y r)\end{array}$ & $\begin{array}{l}\text { Body- } \\
\text { weight } \\
(\mathrm{kg})\end{array}$ & $\begin{array}{l}\text { WHO- } \\
\text { stage }\end{array}$ & $\begin{array}{l}\text { Serum } \\
\text { creatinine }\end{array}$ & $\begin{array}{l}\text { Final dosage } \\
\text { alprenolol } \\
\text { (mg/day) }\end{array}$ & $\begin{array}{l}\text { Final dosage } \\
\text { alpha-methyl-DOPA } \\
\text { (mg/day) }\end{array}$ \\
\hline I & 53 & $104 \cdot 2$ & I & $\mathbf{I} \cdot \mathbf{I}$ & 800 & I500 \\
\hline 2 & .53 & $108 \cdot 0$ & I & $\mathbf{I} \cdot \mathbf{2}$ & 800 & I500 \\
\hline 3 & 52 & $77 \cdot 5$ & I & $I \cdot 0$ & 800 & I500 \\
\hline $4^{\star}$ & 52 & $77 \cdot 0$ & I & 0.9 & dropped out of study & \\
\hline 5 & 52 & $74 \cdot 7$ & I & 0.9 & 400 & 1500 \\
\hline 6 & 52 & $74 \cdot 5$ & II & $\mathbf{I} \cdot 0$ & 800 & 1500 \\
\hline 7 & 52 & $74 \cdot 5$ & I & $1 \cdot 0$ & 800 & 750 \\
\hline 8 & 52 & $72 \cdot 0$ & I & 0.7 & 400 & I500 \\
\hline 9 & 52 & $75 \cdot 0$ & I & $\mathbf{I} \cdot \mathbf{I}$ & 800 & 1500 \\
\hline 10 & 52 & $78 \cdot 0$ & I & $\mathbf{I} \cdot \mathbf{O}$ & 400 & 1500 \\
\hline II & $5 \mathrm{I}$ & $104 \cdot 4$ & I & 0.9 & 800 & 1500 \\
\hline 12 & 52 & $117 \cdot 5$ & I & 0.9 & 800 & 1500 \\
\hline 13 & 52 & 90.0 & I & $1 \cdot 0$ & 800 & 1500 \\
\hline 14 & 52 & $70 \cdot 0$ & I & $1 \cdot 0$ & 800 & 1500 \\
\hline & 43 & $96 \cdot 0$ & I & $I \cdot 0$ & 800 & 1500 \\
\hline Mean & $51 \cdot 5$ & $86 \cdot 2$ & & $1 \cdot 0$ & & \\
\hline
\end{tabular}

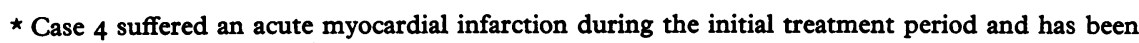
excluded from the evaluation.

previously prepared questionnaire. The adherence to the medication was checked throughout by counting the number of tablets remaining at each visit.

The participants of the trial arrived at the out-patient department every four weeks between 4 and $6 \mathrm{pm}, 2$ to 4 hours after intake of the last methyldopa dose or 8 to ro hours after the last alprenolol dose. Immediately after arrival, each subject was placed on a tilt table and allowed to rest in the supine position for 5 minutes. During the final minute two blood pressure readings were taken. The subjects were then tilted to the erect position. Blood pressures and heart rates were recorded after 2,4 , and 8 minutes. Thereafter the subjects performed exercise amounting to $100 \mathrm{~W}(600 \mathrm{kpm} / \mathrm{min})$ on an electronically braked bicycle ergometer (ElemaSchönander) for 5 minutes. During the final minute a duplicate blood pressure reading was taken and the pulse rate recorded. During exercise, only systolic blood pressure was registered. Each time the blood pressure was measured the pulse rate was simultaneously recorded on a standard electrocardiogram.

All blood pressure determinations were performed using a standard mercury manometer and reading to the nearest $2 \mathrm{~mm}$. Cuff and stethoscope application was rigidly standardized to ascertain identical placing every time.

After exercise the patients were questioned concerning subjective adverse effects according to the questionnaire.

Before admission of each patient to the trial standard biochemical hepatic and renal function tests ware performed. Throughout the study these observations were regularly repeated.

Mean values were calculated from all duplicate blood pressure readings. All values are presented as mean values plus or minus the standard error of the mean. The results were subjected to statistical analysis by means of Student's t-test, paired and unpaired, and analysis of variance including Scheffé's contrast (Scheffé, 1953).

\section{Results}

The responses of the individual patients with regard to resting supine pressures are presented in Table 2.

One patient (Case 4) suffered an acute nonfatal myocardial infarction during the initial methyldopa treatment and was excluded from the evaluation.

On entrance to the trial there was no significant difference in blood pressure between the two groups either supine, standing at rest, or during exercise. After the initial treatment period and the 'wash-out period', however, 5 of the 7 patients initially treated with alprenolol (group I) failed to return to the initial supine pressure levels (Table 2). The systolic and diastolic pressures recorded after the 'wash-out period' in group I remained significantly lower than the initial pressures $(P<0.05)$ (Fig.). The statistical model for analysis of crossover data was thereby destroyed, and the results are therefore presented in the following way.

I) Blood pressures and heart rate on each drug compared to initial levels for each group, supine and erect.

2) Comparison of alprenolol (group I) and methyldopa (group 2) during period I, supine and erect. 
TABLE 2 Supine systolic and diastolic pressures $(\mathrm{mmHg})$ for 14 patients before treatment, on final dosage levels of alprenolol and methyldopa, and pressures at end of intermediate 'wash-out period'

\begin{tabular}{|c|c|c|c|c|}
\hline Case No. & $\begin{array}{l}\text { Initial } \\
\text { value }\end{array}$ & $\begin{array}{l}\text { Alprenolol } \\
\text { final dosage }\end{array}$ & Wash-out & $\begin{array}{l}\text { Methyldopa, } \\
\text { final dosage }\end{array}$ \\
\hline \multicolumn{5}{|l|}{ Group $I$} \\
\hline I & I89/129 & $177 / 104$ & $194 / 128$ & $180 / 125$ \\
\hline 3 & $156 / 105$ & I55/106 & I57/103 & $142 / 94$ \\
\hline 6 & $181 / 116$ & $136 / 91$ & I4I/99 & I56/10I \\
\hline 7 & $182 / 122$ & II I /84 & 153/99 & $128 / 83$ \\
\hline 9 & $165 / 112$ & $156 / 106$ & $156 / 107$ & $157 / 107$ \\
\hline 10 & $180 / 110$ & $145 / 89$ & $147 / 98$ & $139 / 86$ \\
\hline 15 & $164 / 106$ & $135 / 85$ & $156 / 100$ & $125 / 88$ \\
\hline $\begin{array}{l}\text { Mean } \\
\text { SEM }\end{array}$ & $\begin{array}{l}174 / 114 \\
4 \cdot 6 / 3 \cdot 3\end{array}$ & $\begin{array}{l}145 / 95 \\
7 \cdot 8 / 3 \cdot 8\end{array}$ & $\begin{array}{l}158 / 105 \\
6 \cdot 4 / 4 \cdot 0\end{array}$ & $\begin{array}{l}147 / 98 \\
7 \cdot 2 / 2 / 5 \cdot 6\end{array}$ \\
\hline Case No. & $\begin{array}{l}\text { Initial } \\
\text { value }\end{array}$ & $\begin{array}{l}\text { Methyldopa, } \\
\text { final dosage }\end{array}$ & Wash-out & $\begin{array}{l}\text { Alprenolol, } \\
\text { final dosage }\end{array}$ \\
\hline \multicolumn{5}{|l|}{ Group 2} \\
\hline 2 & $196 / 110$ & $162 / 105$ & $200 / 118$ & $175 / 100$ \\
\hline 5 & $163 / 113$ & $164 / 116$ & $166 / 108$ & $145 / 94$ \\
\hline 8 & $171 / 166$ & $162 / 101$ & 165/10r & $139 / 85$ \\
\hline II & $170 / 107$ & 169/108 & $181 / 107$ & $145 / 85$ \\
\hline 12 & $196 / 118$ & $203 / 117$ & $203 / 100$ & $190 / 89$ \\
\hline 13 & I68/I I4 & I63tio4 & $207 / 122$ & $156 / 94$ \\
\hline 14 & $159 / 107$ & $155 / 97$ & $170 / 108$ & $155 / 93$ \\
\hline Mean & $175 / 112$ & 168/107 & $185 / 111$ & $158 / 91$ \\
\hline SEM & $5 \cdot 7 / 1 \cdot 6$ & $6 \cdot 0 / 2 \cdot 8$ & $7 \cdot 0 / 2 \cdot 7$ & $6 \cdot 9 / 2 \cdot 1$ \\
\hline
\end{tabular}

Case 4 has been excluded.

3) Comparison of methyldopa and alprenolol in group I and 2.

4) Systolic blood pressure and heart rate during exercise.

5) Number of responders to each drug at each dosage level.

6) Laboratory findings and subjective side-effects.

On counting the number of tablets returned at each visit it was found that the patients were strictly following the regimen prescribed.

I) Blood pressures and heart rate on each drug compared to initial levels for each group, supine and erect

Group I A mean pressure reduction of $28 \mathrm{mmHg}$ systolic and $19 \mathrm{mmHg}$ diastolic was recorded with the final dosage level of alprenolol. The final pressures of $145 \pm 7.8 \mathrm{mmHg}$ systolic and $95 \pm 3.8$ $\mathrm{mmHg}$ diastolic were both significantly lower than the initial pressures $(\mathrm{P}<0.0 \mathrm{I})$ (Table 2) (Fig. I).
Alprenolol significantly reduced both systolic and diastolic readings with the participants supine. Similar reductions were observed after 2,4 , and 8 minutes of standing (Table 3 ).

The heart rate was not significantly lowered either supine or standing (Table 4).

Group 2 The average pressures resulting from methyldopa treatment were $168 \pm 6.0 \mathrm{mmHg}$ systolic and $107 \pm 2.8 \mathrm{mmHg}$ diastolic corresponding to a mean decrease of $7 \mathrm{mmHg}$ systolic and $5 \mathrm{mmHg}$ diastolic. The final pressures were not significantly different from the initial pressures (Table 2).

The effect of methyldopa on standing systolic and diastolic blood pressures was less than for alprenolol (Table 3). After two minutes of standing the blood pressure was lowered by $14 \mathrm{mmHg}$ systolic and $9 \mathrm{mmHg}$ diastolic. This erect diastolic difference was significant $(P<0.02)$.

The heart rate was not significantly changed either supine or standing (Table 4). 


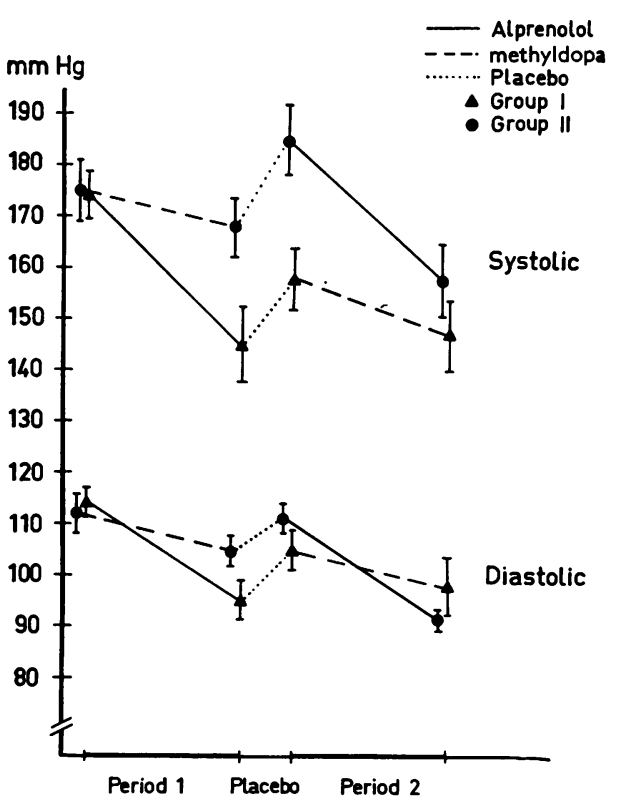

FIG. Supine systolic and diastolic blood pressures before treatment, during final alprenolol and methyldopa, and after an intermediate four weeks of placebo administration.
2) Comparison of alprenolol (group I) and methyldopa (group 2) during period I, supine and erect

Resting supine Final dosage levels of alprenolol (group I) produced supine systolic and diastolic pressures significantly lower than methyldopa (group 2) $(P<0.005)$ (Table 2).

There was no significant difference in resting supine heart rates between the two groups (Table 4).

Erect During treatment with the final doses and after two minutes of standing the mean arterial systolic and diastolic blood pressures in group I (alprenolol) were $134 \pm 5.5 \mathrm{mmHg}$ systolic and $109 \pm 3.9 \mathrm{mmHg}$ diastolic, compared to $167 \pm 6.5$ $\mathrm{mmHg}$ systolic and $112 \pm 2 \cdot 2 \mathrm{mmHg}$ diastolic for group 2 (methyldopa) (Table 3). The systolic pressures differ significantly $(P<0.01)$. These findings are corroborated after 8 minutes $(P<0.05)$. A comparison of the heart rates in both groups showed no significant differences (Table 4).

During the investigation no overt orthostatic reactions were encountered.

\section{3) Comparison of methyldopa and alprenolol in group $I$ and 2}

The final doses of alprenolol in group 2 produced a

TABLE 3 Mean systolic and diastolic pressures ( $\mathrm{mmHg}$ ) with standard errors of the means $(S E M)$ in erect position after 2, 4, and 8 minutes and after 4 minutes of exercise (bicycle ergometer, $100 W$ ) (during exercise only systolic pressures are presented)

\begin{tabular}{|c|c|c|c|c|}
\hline & $\begin{array}{l}\text { Initial } \\
\text { value }\end{array}$ & $\begin{array}{l}\text { Alphrenolol, } \\
\text { final dosage }\end{array}$ & Wash-out & $\begin{array}{l}\text { Methyldopa, } \\
\text { final dosage }\end{array}$ \\
\hline \multirow[t]{2}{*}{$\begin{array}{l}\text { Group I } \\
\text { BP erect } 2 \mathrm{~min} \\
\text { SEM } \\
\text { BP erect } 4 \mathrm{~min} \\
\text { SEM } \\
\text { BP erect } 8 \mathrm{~min} \\
\text { SEM } \\
\text { Systolic BP exercise } \\
\text { SEM }\end{array}$} & $\begin{array}{l}180 / 128 \\
2 \cdot 1 / 2 \cdot 2 \\
181 / 129 \\
4 \cdot 2 / 2 \cdot 6 \\
187 / 132 \\
4 \cdot 0 / 4 \cdot 1 \\
222 \\
5 \cdot 4\end{array}$ & $\begin{array}{l}134 / 109 \\
5.5 / 3.9 \\
150 / 109 \\
7.9 / 3.8 \\
141 / 107 \\
5.9 / 4 \cdot 1 \\
196 \\
8.9\end{array}$ & $\begin{array}{l}158 / 117 \\
5.6 / 3.0 \\
161 / 114 \\
6.9 / 2.7 \\
159 / 115 \\
5.8 / 2 \cdot 6 \\
213 \\
7.9\end{array}$ & $\begin{array}{l}142 / 106 \\
6 \cdot 5 / 2 \cdot 2 \\
140 / 108 \\
6 \cdot 7 / 2 \cdot 3 \\
145 / 106 \\
6 \cdot 2 / 2 \cdot 7 \\
195 \\
7 \cdot 2\end{array}$ \\
\hline & $\begin{array}{l}\text { Initial } \\
\text { value }\end{array}$ & $\begin{array}{l}\text { Methyldopa, } \\
\text { final dosage }\end{array}$ & Wash-out & $\begin{array}{l}\text { Alprenolol, } \\
\text { final dosage }\end{array}$ \\
\hline $\begin{array}{l}\text { Group } 2 \\
\text { BP erect } 2 \text { min } \\
\text { SEM } \\
\text { BP erect } 4 \mathrm{~min} \\
\text { SEM } \\
\text { BP erect } 8 \mathrm{~min} \\
\text { SEM } \\
\text { Systolic BP exercise } \\
\text { SEM }\end{array}$ & $\begin{array}{l}181 / 121 \\
5 \cdot 6 / 3 \cdot 0 \\
180 / 121 \\
4 \cdot 2 / 2 \cdot 9 \\
179 / 125 \\
6 \cdot 3 / 3 \cdot 3 \\
233 \\
7 \cdot 9\end{array}$ & $\begin{array}{l}167 / 112 \\
6 \cdot 5 / 2 \cdot 2 \\
163 / 113 \\
7 \cdot 0 / 1 \cdot 6 \\
166 / 111 \\
7 \cdot 5 / 2 \cdot 0 \\
220 \\
6.9\end{array}$ & $\begin{array}{l}185 / 121 \\
5 \cdot 9 / 1 \cdot 7 \\
186 / 118 \\
5 \cdot 2 / 1 \cdot 0 \\
188 / 120 \\
5 \cdot 4 / 1 \cdot 4 \\
246 \\
6 \cdot 5\end{array}$ & $\begin{array}{l}156 / 102 \\
7 \cdot 2 / 2 \cdot 6 \\
156 / 106 \\
6 \cdot 0 / 2 \cdot 6 \\
161 / 108 \\
7 \cdot 2 / 1 \cdot 6 \\
218 \\
8 \cdot 5\end{array}$ \\
\hline
\end{tabular}


TABLE 4 Mean heart rates (beats/min) and standard error of the means (SEM) (I4 patients) supine, erect ( 2 min), and during exercise

\begin{tabular}{|c|c|c|c|c|}
\hline & $\begin{array}{l}\text { Mean heart } \\
\text { Initial value }\end{array}$ & $\begin{array}{l}\text { tes (beats/min) } \\
\text { Alprenolol, } \\
\text { final dosage }\end{array}$ & Wash-out & $\begin{array}{l}\text { Methyldopa, } \\
\text { final dosuge }\end{array}$ \\
\hline \multirow[t]{2}{*}{$\begin{array}{l}\text { Group I } \\
\text { Supine } \\
\text { Erect } 2 \mathrm{~min} \\
\text { Exercise }\end{array}$} & $\begin{array}{r}72(4.8) \\
77(5.4) \\
122(5.5)\end{array}$ & $\begin{array}{r}66(3.4) \\
80(2.8) \\
133(5.7)\end{array}$ & $\begin{array}{r}75(4 \cdot 0) \\
86(3 \cdot 7) \\
123(4 \cdot 3)\end{array}$ & $\begin{array}{r}73(4 \cdot 5) \\
85(3 \cdot 3) \\
125(5 \cdot 2)\end{array}$ \\
\hline & Initial value & $\begin{array}{l}\text { Methyldopa, } \\
\text { final dosage }\end{array}$ & Wash-out & $\begin{array}{l}\text { Alprenolol, } \\
\text { final dosage }\end{array}$ \\
\hline $\begin{array}{l}\text { Group } 2 \\
\text { Supine } \\
\text { Erect } 2 \mathrm{~min} \\
\text { Exercise }\end{array}$ & $\begin{array}{r}77(4.3) \\
85(3.9) \\
130(4.6)\end{array}$ & $\begin{array}{r}73(2 \cdot 7) \\
84(2 \cdot 5) \\
125(5 \cdot 0)\end{array}$ & $\begin{array}{r}81(3.1) \\
87(5.4) \\
\text { I3I }(4 . I)\end{array}$ & $\begin{array}{r}67(3 \cdot 0) \\
71(3 \cdot 2) \\
\text { I } 10(5 \cdot 8)\end{array}$ \\
\hline
\end{tabular}

mean supine systolic blood pressure significantly lower than during the previous 'wash-out period' $(27 \mathrm{mmHg}, \mathrm{P}<0.01)$. The diastolic blood pressure obtained with the final alprenolol doses was significantly lower than both the previous 'wash-out period' (20 mmHg, $\mathrm{P}<0.0 \mathrm{I}$ ) and also than the mean diastolic pressure during treatment with methyldopa (I6 mmHg, $\mathrm{P}<0.025$ ) (Table 2) (Fig.). With respect to standing pressures after 2,4 , and 8 minutes the systolic and diastolic pressures recorded during treatment with alprenolol (period II) were significantly lower than those during the 'wash-out period' $(\mathbf{P}<0.01)$ except for the diastolic pressure after 8 minutes. No other statistically significant changes were observed in group 2.

In group I, after treatment with the final doses of methyldopa (period II), the average systolic and diastolic pressures were almost identical to those recorded during the final alprenolol dosage.

4) Systolic blood pressure and heart rate during exercise

Systolic blood pressures and heart rates during exercise are presented in Tables 3 and 4. Both drugs showed a tendency to lower the systolic pressure compared to the preceding initial or placebo periods. Neither the difference between the active treatment and initial or placebo periods nor between the two drugs was statistically significant.

Alprenolol lowered the heart rate in both groups, most obviously in group 2 ( 2 I beats/min, $\mathbf{P}<0.01$ ) (Table 4).

\section{5) Number of responders to each drug at each dosage level}

Patients with post-treatment pressures below I60 $\mathrm{mmHg}$ systolic and $95 \mathrm{mmHg}$ diastolic were defined as responders, and 9 patients showed a satisfactory response to treatment with alprenolol. The corresponding figure for methyldopa was 4 patients.

Among the responders, $400 \mathrm{mg}$ daily of alprenolol produced a satisfactory blood pressure response in 3 patients. Thus, the remaining 6 alprenolol responders required $800 \mathrm{mg}$ daily. One patient responded satisfactorily to a daily dose of $750 \mathrm{mg}$ of methyldopa and the remaining 3 patients thus responded to $1500 \mathrm{mg}$ daily. Those 4 patients all received methyldopa as the second drug.

\section{6) Laboratory findings and subjective side- effects}

There were no instances of haemolysis or positive Coombs tests. Two patients developed rise in SGOT during methyldopa treatment ( $1.5 \mathrm{~g}$ daily). These returned to normal after change of therapy.

There were no great differences in subjective side-effects between the two trial drugs (Table 5). One patient (Case II) had such severe subjective adverse drug effects (depression) after three months of methyldopa ( $1.5 \mathrm{~g}$ daily) that this treatment would have had to be discontinued. However, the patient was due for a change of treatment accord- 
TABLE 5 Subjective side-effects: number of complaints according to questionnaire and number of patients without complaints (all severe side-effects were reported at one interview by same patient)

\begin{tabular}{|c|c|c|c|c|c|c|}
\hline & \multicolumn{2}{|c|}{$\begin{array}{l}\text { Alprenolol, } \\
\text { final dosage }\end{array}$} & \multicolumn{2}{|l|}{ Placebo } & \multicolumn{2}{|c|}{$\begin{array}{l}\text { Methyldopa, } \\
\text { final dosage }\end{array}$} \\
\hline & Tolerable & Severe & Tolerable & Severe & Tolerable & Severe \\
\hline Palpitations & - & - & I & - & - & - \\
\hline Dizziness & I & - & - & - & I & - \\
\hline Sedation & 2 & - & 2 & - & 4 & $\mathbf{I}$ \\
\hline Disturbance of sleep & 4 & - & I & - & I & - \\
\hline Nausea & I & - & - & - & - & - \\
\hline Dryness of mouth & I & - & - & - & 3 & $\mathbf{I}$ \\
\hline Bronchospasm & - & - & - & - & I & - \\
\hline Muscular fatigue & I & - & $\mathbf{I}$ & - & - & - \\
\hline Diarrhoea & 2 & - & - & - & - & - \\
\hline Constipation & - & - & - & - & - & I \\
\hline $\begin{array}{l}\text { Headache } \\
\text { Hectis }\end{array}$ & - & - & I & - & I & - \\
\hline Depression & $\mathbf{I}$ & - & - & - & - & I \\
\hline Decreased libido & I & - & - & - & I & - \\
\hline $\begin{array}{l}\text { Total number of } \\
\text { complaints }\end{array}$ & 14 & 0 & 6 & 0 & 12 & 4 \\
\hline $\begin{array}{l}\text { Total number of } \\
\text { patients without } \\
\text { any side-effects }\end{array}$ & 8 & & Io & & 6 & \\
\hline
\end{tabular}

ing to the trial schedule, and he could, therefore, complete the study.

During the intermediate 'wash-out period' ro out of 14 patients were completely free from sideeffects. During treatment with the final dosage the corresponding figure for alprenolol was 8 and for methyldopa 6 patients.

\section{Discussion}

For many years methyldopa has been one of the most important antihypertensive drugs. Several reports have indicated its antihypertensive properties (Oates et al., 1960; Onesti et al., 1962; Mohammed et al., 1969; Winer et al., 1969). Betablockers have been used as antihypertensive agents for 5 to 6 years. Studies during this period have conclusively shown the value of these drugs (Paterson and Dollery, 1966; Prichard and Gillam, 1966; Åblad et al., 1967; Johnsson et al., 1969; Tibblin and Áblad, 1969; Zacharias and Cowen, 1970; Zacharias et al., 1972; Sannerstedt et al., 1971, 1972; Bengtsson, 1972; Hansson et al., 1972).

The published reports seem to contain no direct comparative trial of beta-blockers and methyldopa. When designing the present study, it was difficult to define comparable dosage levels of these two agents which differ in their sites of action. Two commonly used and accepted dosage levels for each drug were therefore used in order to obtain an optimal response in each patient and the effects of the final dosage levels of both drugs have been compared.

All variables under study were recorded blindly as regards type of treatment. The differences between the two drugs, i.e. with regard to the heart rate, were never sufficient to disclose the type of treatment to the observers during the course of the study. The significant reduction of the exercise heart rate during alprenolol supports the impression of good patient co-operation with regard to tablet intake.

The patients were selected in order to obtain a sample as homogeneous as possible with regard to sex, age, freedom from previous antihypertensive treatment, and stage of the disease. It was hoped that this would decrease the necessary size of the sample.

An interesting finding was that the group initially receiving alprenolol did not reurn to the initial pressure levels after 3 months of active treatment and I month of placebo. The reason for this sustained effect of alprenolol is unclear. The antihypertensive effect of beta-blockers is probably due to many factors. The most important one seems to be reduction of the cardiac output due to blockade 
of the cardiac beta-receptors. This effect may be observed during acute experiments and is probably the cause of the almost immediate reduction of blood pressure given by these drugs. However, beta-blockers also seem to produce a delayed effect on the arterial blood pressure. This latter effect is apparent after I to 2 months (Paterson and Dollery, 1966; Prichard and Gillam, 1966; Zacharias et al., 1972). Prichard and Gillam (1969) have suggested that this delayed effect is due to 'resetting' of the baroreceptors. This effect probably also disappears slowly.

This 'delayed' effect on the arterial blood pressure is probably not unique for beta-blockers. The reason why methyldopa did not induce the same long-lasting effect on the blood pressure as alprenolol in the present study might be due to a different haemodynamic pattern with this drug, with less pronounced effects on the 'resetting' mechanism.

Other factors may be involved in the delayed return to the initial pressure levels of the patients starting with alprenolol. It is now established that beta-receptor blockade reduces the peripheral renin activity (Winer et al., 1969). Laragh has presented the theory that the induced change in peripheral renin activity is the primary factor underlying the antihypertensive effect of beta-adrenergic blockade (Bühler et al., 1972). This theory, however, has been questioned by other investigators (Hansson and Zweifler, 1973). It is unlikely that the probable changes in peripheral renin activity during treatment with alprenolol are responsible for the difference between the two trial durgs since methyldopa also lowers the peripheral renin activity (Mohammed et al., 1969).

On the other hand, it may be possible that the more pronounced blood pressure lowering during alprenolol is related to a normal peripheral resistance which has been suggested for propranolol (Tarazi and Dustan, 1972). This effect on the peripheral resistance may, however, be related only to the prolonged pressure reduction per se which may modify the structure of the wall of the peripheral resistance vessels (Sivertsson, 1970).

In the present series, only alprenolol produced a statistically significant effect on the supine and erect systolic and diastolic arterial blood pressures compared to the pressures before active treatment. The reduction is of the same order of magnitude at each dosage level as has been found by other investigators (Tibblin and Åblad, 1969; Bengtsson, 1972).

The reduction of the arterial pressure during treatment with methyldopa is less than that reported by other investigators (Oates et al., 1960; Gillespie et al., 1962; Onesti et al., 1962; Smirk,
1963; Dollery, 1964; Horwitz et al., 1967; Hamilton, 1968; Hilden and Nilsson, 1968). This might be explained by several factors, such as a difference in dosage. Also, our patients might not be comparable to those of other trials. They do, however, represent newly detected cases with early stages of the disease and might be expected to be more rather than less sensitive to treatment. In the group of patients initially treated with methyldopa and then with alprenolol, alprenolol produced a more pronounced reduction of blood pressure. However, alprenolol was favoured in comparison to methyldopa in this group, since it was introduced as the second drug.

In most of the above-mentioned studies methyldopa was not studied singly. The limited response to methyldopa in the present study is in accordance with previous experience, but most authors would like to have a saluretic agent routinely given together with methyldopa in order to get the best benefit with this agent. We purposely avoided this as we wanted to compare the effect of the drugs without interference from other agents.

A controlled comparative trial of propranolol and methyldopa was recently published (Brahm, 1973). No difference with regard to pressure effects could be detected, but it should be noted that fixed doses of hydrochlorothiazide were administered throughout the study, and that the duration of the treatment periods was not fixed.

Systolic blood pressure during exercise could not be shown to be significantly lower during treatment than before. There was no trend towards one drug being superior to the other.

In recent years several reports have dealt with the side-effects of methyldopa, e.g. haemolytic anaemia, positive Coombs tests, sedation, and depression (Carstairs et al., I966; Worlledge, Carstairs, and Dacie, 1966; Prichard et al., 1968; Hunter, Raik, and Gordon, 197I). Deranged liver function tests have also been reported (Sheps et al., 1963). Raised SGOT levels were found in 2 of our patients. Heavy sedation and frank depression were found in I patient treated with $1.5 \mathrm{~g}$ of methyldopa daily. Otherwise there were no differences between the drugs. In no case did bronchoconstriction, bronchial asthma, or cardiac decompensation occur during treatment with alprenolol. In the patient with myocardial infarction there was never any reason to assume that the trial drug had any causal connexion with the outcome.

The limited number of patients restricts the possibilities of drawing generalized conclusions from the present results, but the evidence suggests that in the doses tested alprenolol has greater potency than methyldopa as an antihyperten- 
sive agent. Alprenolol is, therefore, well suited to be used alone as an alternative to methyldopa in treating previously untreated moderate hypertension.

\section{References}

Åblad, B., Brogård, M., and Ek, L. (1967). Pharmacological properties of $\mathrm{H}_{56 / 28}-\mathrm{a}$ beta-adrenergic receptor antagonist. Acta Pharmacologica et Toxicologica, 25, 9.

Bengtsson, C. (1972). Comparison between alprenolol and chlorthalidone as antihypertensive agents. Acta Medica Scandinavica, 191, 433.

Brahm, M. (1973). Comparison between propranolol and methyldopa in the treatment of hypertension. A double blind trial. Ugeskrift for Laeger, 135, 974.

Bühler, F. R., Laragh, J. H., Baer, L., Vaughan. E. D., and Brunner, H. R. (1972). Propranolol inhibition of renin secretion. New England fournal of Medicine, 287, 1209.

Carstairs, K. C., Breckenridge, A., Dollery, C. T., and Worlledge, S. M. (1966). Incidence of a positive direct Coomb's test in patients on $x$-methyldopa. Lancet, 2, 133.

Dollery, C. T. (1964). Alpha-methyldopa in the treatment of hypertension. Medical Clinics of North America, 48, 335 .

Gillespie, L., Jr., Oates, J. A., Crout, J. R., and Sjoerdsma, A. (1962). Clinical and chemical studies with a alphamethyldopa in patients with hypertension. Circulation, 25, 281 .

Hamilton, M. (1968). Some aspects of the long-term treatment of severe hypertension with methyldopa. Postgraduate Medical fournal, 44, 66.

Hansson, L., Malmcrona, R., Olander, R., Rosenhall, L., Westerlund, A., Åberg, H., and Hood, B. (1972). Proppranolol in hypertension. Report on 158 patients treated up to one year. Klinische Wochenschrift, 50, 364.

Hansson, L., and Zweifler, A. J. (1973). The effect of propranolol on plasma renin activity and blood pressure in essential hypertension. Acta Medica Scandinavica. In the press.

Hilden, T., and Nilsson, R. (1968). Methyldopa i behandlingen af hypertension. Tidsskrift for den Norske Laegeforening, 88, 1416.

Horwitz, D., Pettinger, W. A., Orvis, H., and Sjoerdsma, A. (1967). Effects of methyldopa in fifty hypertensive patients. Clinical Pharmacology and Therapeutics, 8, 224.

Hunter, E., Raik, E., and Gordon, S. (197I). Incidence of positive Coomb's test, LE-cells and antinuclear factor in patients on alpha-methyldopa (Aldomet) therapy. Medical fournal of Australia, 2, 810 .

Johnsson, G., de Guzman, M., Bergman, H., and Sannerstedt, R. (1969). The haemodynamic effects of alprenolol and propranolol at rest and during exercise in hypertensive patients. Pharmacologia Clinica, 2, 34.

Mohammed, S., Fasola, A. F., Privitera, P. J., Lipicky, R. J., Martz, B. L., and Gaffney. T. E. (1969). Effect of methyldopa on plasma renin activity in man. Circulation Research, 25, 543 .
Oates, J. A., Gillespie, L., Udenfriend, S., and Sjoerdsma, A. (1960). Decarboxylase inhibition and blood pressure reduction by alpha-methyl 3, 4-dihydroxy-DL-phenylalanine. Science, 131, 1890.

Onesti, G., Brest, A. N., Novack, P., and Moyer, J. H. (I962). Pharmacodynamic effects and clinical use of alpha methyldopa in the treatment of essential hypertension. American fournal of Cardiology, 9, 863.

Paterson, J. W., and Dollery, C. T. (1966). Effect of propranolol in mild hypertension. Lancet, 2, 1148.

Prichard, B. N. C., and Gillam, P. M. S. (1966). Propranolol in hypertension. American fournal of Cardiology, 18, 387.

Prichard, B. N. C., and Gillam, P. M. S. (1969). Treatment of hypertension with propranolol. British Medical fournal, I, 7.

Prichard, B. N. C., Johnstone, A. W., Hill, I. D., and Rosenheim, M. L. (1968). Bethanidine, guanethidine, and methyldopa in treatment of hypertension: a withinpatient comparison. British Medical fournal, I, 135.

Sannerstedt, R., Stenberg, J., Johnson, G., and Werkö, L. (197I). Hemodynamic interference of alprenolol with dihydralazine in normal and hypertensive man. American fournal of Cardiology, 28, 316.

Sannerstedt, R., Stenberg, J., Vedin, A., Wilhelmsson, C., and Werkö, L. (1972). Chronic beta adrenergic blockade in arterial hypertension. American fournal of Cardiology, 29, 718.

Scheffe, H. (1953). A method for judging all contrasts in the analysis of variance. Biometrika, 40, 87 .

Sheps, S. G., Schirger, A., Osmundson, P. J., and Fairbairn, J. F. (1963). Methyldopa for treatment of hypertension. Fournal of the American Medical Association, 184, 616.

Sivertsson, R. ( 1970 ). The hemodynamic importance of structural vascular changes in essential hypertension. Acta Physiologica Scandinavica, Suppl. 343, I.

Smirk, H. (1963). Hypotensive action of methyldopa. British Medical fournal, $\mathrm{I}, \mathrm{I} 46$.

Tarazi, R. C., and Dustan, H. P. (1972). Beta adrenergic blockade in hypertension. American fournal of Cardiology, 29, 633 .

Tibblin, G., and Åblad, B. (1969). Antihypertensive therapy with alprenolol, a beta-adrenergic receptor antagonist. Acta Medica Scandinavica, 186, 451.

Winer, N., Chokshi, D. S., Yoon, M. S., and Freedman, A. D. (1969). Adrenergic receptor mediation of renin secretion. Fournal of Clinical Endocrinology and Metabolism, 29, 1168 .

Worlledge, S. M., Carstairs, K. C., and Dacie, J. V. (1966). Autoimmune haemolytic anaemia associated with alpha methyldopa therapy. Lancet, 2, 135.

Zacharias, F. J., and Cowen, K. J. (1970). Controlled trial of propranolol in hypertension. British Medical fournal, $\mathbf{I}$, 471 .

Zacharias, F. J., Cowen, K. J., Prestt, J., Vickers, J., and Wall, B. G. (1972). Propranolol in hypertension. A study of long-term therapy, 1964-1970. American Heart fournal, 83, 755 .

Requests for reprints to Dr. Claes-E. Wilhelmsson, Department of Medicine I, Sahlgren's Hospital, 41345 Gothenburg, Sweden. 